Corrigendum:

(C) 1986 Birkhäuser Vorlag, Basel

Table 1 \& should show

Table 32 plagioclase feldspar

$2 \mathrm{Na}_{0.5} \mathrm{Ca}_{0.5} \mathrm{Al}_{1.5} \mathrm{Si}_{2.5} \mathrm{O}_{8}$

Table 3 should be 7.5 moles

of $\mathrm{CaCO}_{3}$ or anorthite

\title{
The role of chemical weathering in the neutralization of acidic deposition
}

\section{Dedicated to Wolfgang Geiger}

\section{By Jerald L. Schnoor') and Werner Stumm²)}

1) Dept. of Civil and Environmental Engineering, University of lowa, lowa City, USA

2) Institute for Water Resources and Water Pollution Control (EAWAG), Swiss Federal Institute of Technology (ETH), Zürich, Switzerland

Manuscript received on 27 March 1986

\begin{abstract}
Chemical weathering of rocks and minerais is a key factor which mitigates acidic deposition and affects water chemistry. It supplies cations and alkalinity to the surface water, groundwater, ion-exchange complex, and vegetation in the watershed. The kinetics of chemical weathering have not been determined in the field, but based on laboratory experiments, the rate of weathering has a fractional order dependency on hydrogen ion and organic ligand concentration in bulk solution. Watersheds with the greatest degree of hydrologic and geologic sensitivity can produce only $200-500 \mathrm{eq} / \mathrm{ha} \cdot \mathrm{yr}$ of cations or alkalinity for export. This is equivalent to $100 \mathrm{~cm} / \mathrm{yr}$ of precipitation with a $\mathrm{pH}$ of $4.3-4.6$ or an annual sulfur deposition of $1.0-2.5 \mathrm{~g} \mathrm{~S} / \mathrm{m}^{2} \cdot \mathrm{yr}$. When acid and sulfur deposition are greater than these levels, extremely sensitive lakes may become acidified. To illustrate this point, a simple steady-state model is applied to lakes in regions where acidification of lakes has been reported.
\end{abstract}

\section{Introduction}

Chemical weathering can be defined as the dissolution of minerals by the action of water and its solutes. It is an important feature of the global hydrogeochemical cycle of elements, whereby rocks and primary minerals become transformed to solutes and soils and, eventually, to sediments and sedimentary rocks. In this cycle, water occupies a central position serving both as a reactant and as a transporting agent of suspended and dissolved material. The sea is the ultimate receptable of weathered material, and the atmosphere provides a reservoir of weak acids $\left(\mathrm{CO}_{2}\right)$ and oxidants.

The occurrence of acid deposition results from the anthropogenic disturbance of cycles that couple atmosphere, land and water. Redox conditions in the atmosphere are disturbed by the oxidation of carbon, sulfur and nitrogen resulting from fossil fuel combustion. Oxidation reactions exceed reduction reactions in the elemental cycles, and a net production of hydrogen ions in atmospheric precipitation is a necessary consequence. The disturbance is transferred to the terrestrial and aquatic environment where, either acidity is neutralized via acid-base and reduction reactions, or the disturbance is transported downstream. 
Atmospheric gases and dust contribute to a mixture of acids, bases and neutral salts in rain water. Reactions in the terrestrial and aquatic environment, such as ammonia oxidation (nitrification) and synthesis of biomass are acidifying influences in the watershed which may rival or exceed acid loading from the atmosphere [1]. In addition, there exist several reactions which can neutralize acidic deposition in the terrestrial and aquatic environment. Such processes can be depicted as denitrification, sulfate reduction and chemical weathering. Sulfate is nearly conservative in many watersheds where sulfate sorbing soils are not prevalent $[2,3]$, and reduction reactions are generally of less importance than chemical weathering in well-drained soils. Since stream and lake water usually contain greater concentrations of alkalinity, anions and cations than precipitation, it follows that chemical weathering of minerals is an important process in the neutralization of acidic deposition.

In this article, we discuss the chemistry and kinetics of chemical weathering as they apply to neutralization of acid precipitation in soils and water. Chemical weathering of rocks and minerals is a key factor which mitigates acidic deposition. It results in the slight modification of large volumes of soil and rock. The rate of mineral dissolution is related to the acidity of the bulk solution and to the concentration of complex-forming weak acids and anions.

In the northern temperature environment where aquatic effects of acid precipitation have been reported [4-11], variations in chemical weathering and the acidity of deposition often determine the alkalinity of lakes. Chemical weathering is a strong function of the hydrology and the mineralogy of the watershed. Lakes which are sensitive to acid precipitation tend to have 'flashy' hydrographs, where water moves swiftly through steep and shallow soils, or precipitation-dominated hydrologies in which most of the water in the lake comes from precipitation falling directly on the surface of the lake. Sensitive mineralogies include bedrock and overburden lacking in calcium and carbonate minerals, especially granitic crystalline rocks and their metamorphic equivalents (gneisses and schists).

The worldwide average chemical weathering rate is estimated to be approximately 3900 eq/ha-yr [12]. However, the minimum chemical weathering rate that occurs within small watersheds in extremely sensitive settings is only $\sim 200 \mathrm{eq} / \mathrm{ha} \cdot \mathrm{yr}$. Thus, when acid deposition begins to exceed $200 \mathrm{eq} / \mathrm{ha} \cdot \mathrm{yr}$, one can expect to find some sensitive lakes that will acidify. Such is the case for acid lakes in New England, the Adirondacks of New York, Michigan, Norway, Sweden, and even Switzerland.

\section{ANC of natural waters}

Acid neutralization capacity (ANC) of waters can be defined conceptually in terms of carbonaceous alkalinity with reference to a system of $\mathrm{CO}_{2}$ and water, stemming from a proton balance:

$$
[\mathrm{Alk}]=\left[\mathrm{HCO}_{3}^{-}\right]+2\left[\mathrm{CO}_{3}^{2-}\right]+\left[\mathrm{OH}^{-}\right]-\left[\mathrm{H}^{+}\right]
$$

An alternative definition for alkalinity is the equivalent sum of conservative cations (those that do not affect alkalinity) minus the sum of conservative anions, a charge balance: 


$$
\begin{aligned}
{[\mathrm{Alk}]=} & {\left[\mathrm{Na}^{+}\right]+\left[\mathrm{K}^{+}\right]+2\left[\mathrm{Ca}^{2+}\right]+2\left[\mathrm{Mg}^{2+}\right]+\left[\mathrm{NH}_{4}^{+}\right] } \\
& -\left[\mathrm{Cl}^{-}\right]-2\left[\mathrm{SO}_{4}^{2-}\right]-\left[\mathrm{NO}_{3}^{-}\right]
\end{aligned}
$$

Mineral acidity (H-Acy) can be defined as the negative of alkalinity:

$$
\begin{aligned}
{[\mathrm{H}-\mathrm{Acy}]=} & {\left[\mathrm{Cl}^{-}\right]+2\left[\mathrm{SO}_{4}^{2-}\right]+\left[\mathrm{NO}_{3}^{-}\right]-\left[\mathrm{Na}^{+}\right] } \\
& -\left[\mathrm{K}^{+}\right]-2\left[\mathrm{Ca}^{2+}\right]-2\left[\mathrm{Mg}^{2+}\right]-\left[\mathrm{NH}_{4}^{+}\right]
\end{aligned}
$$

It is possible to calculate the overall change in alkalinity (or $\mathrm{H}$-acidity) from the stoichiometry of weathering reactions, ion exchange, redox processes and biological production and respiration (1), but perhaps the easiest way to conceptualize the overall effect is to examine bar diagrams. On a bar diagramm, any process which, as a net effect, serves to increase the concentration of basic cations $\left(\mathrm{Ca}^{2+}, \mathrm{Mg}^{2+}, \mathrm{K}^{+}, \mathrm{NH}_{4}^{+}\right)$adds alkalinity to the water. Any process which serves to increase the concentration of acid anions ( $\mathrm{SO}_{4}^{2-}, \mathrm{NO}_{3}^{-}, \mathrm{Cl}^{-}$) acidifies the water. The acidity is simply the equivalent sum of the acid anions minus the base cations.

\section{Mineralogy and soils}

\subsection{Minerals in soils}

Goldich [13] was the first to notice the analogy between the relative rate that silicate minerals weather and their formation from magma as it cooled. Olivine is the most rapidly weathered mafic mineral (ferromagnesian), while biotite $\left(\mathrm{KMg}_{2} \mathrm{AlSi}_{3} \mathrm{O}_{10}(\mathrm{OH})_{2}\right)$ is the least. Anorthite (Ca-feldspar) is the most rapidly weathered felsic mineral, while albite (Na-feldspar) is the least. The minerals which are most resistant to weathering include $\mathrm{K}$-feldspars, muscovite, and quartz, in rank order. Table 1 gives chemical dissolution equations for some minerals commonly found in soils, in decreasing order of dissolution rate. Calcite is a carbonate mineral that is most easily dissolved in the presence of water and dissolved carbon dioxide. The reactions of table 1 could be written with water and dissolved carbon dioxide $\left(\mathrm{H}_{2} \mathrm{CO}_{3 \text { (aq) }}\right)$ or hydrogen ion $\left(\mathrm{H}^{+}\right)$as the reactants. In any case, the net result of the reaction is the same-cations $\left(\mathrm{Ca}^{2+}, \mathrm{Mg}^{2+}, \mathrm{Na}^{+}, \mathrm{K}^{+}\right)$are released, and alkalinity is produced via $\mathrm{OH}^{-}$or $\mathrm{HCO}_{3}^{-}$production or $\mathrm{H}^{+}$consumption. Table 2 shows that the dissolution of Ca-feldspar (anorthite) yields two equivalents of calcium ions, produces a secondary mineral (kaolinite clay), and consumes two equivalents of acid $\left(\mathrm{H}^{+}\right)$. In all the reactions, the equivalents of cations released are exactly balanced by the equivalents to acid consumed ( = alkalinity produced). Dissolution reactions which have a solid product remaining are termed 'incongruent'. Reactions which produce only soluble species in stoichiometric proportions of the solid phase are congruent dissolution reactions.

The reactions shown in table 1 are not elementary reactions - they may proceed through a series of reaction steps. For example, it is possible that the aluminosilicate feldspars dissolve congruently in the upper soil at low $\mathrm{pH}$, releasing 'base' cations $\left(\mathrm{Ca}^{2+}, \mathrm{Mg}^{2+}, \mathrm{K}^{+}\right.$, $\mathrm{Na}^{+}$) as well as aluminium $\left(\mathrm{Al}^{3+}\right)$. As the soil water percolates, gibbsite is precipitated at higher $\mathrm{pH}$. Eventually, if the concentration of silicic acid $\left(\mathrm{H}_{4} \mathrm{SiO}_{4}\right)$ is large enough, kaolinite or other clays can precipitate from the gibbsite in solution. 
Tuble 1. Some important dissolution reactions in approximate rank order for ease of weathering (from greatest to least). The weathering reactions can be written with $\mathrm{H}_{2} \mathrm{CO}_{3}$ or $\mathrm{H}^{+}$as the reactant. Aluminosilicate minerals can be written with kaolinite as the weathering product (e.g. for anorthite. albite, biotite and orthoclase) or as a congruent dissolution (e. g. for plagioclase feldspar).

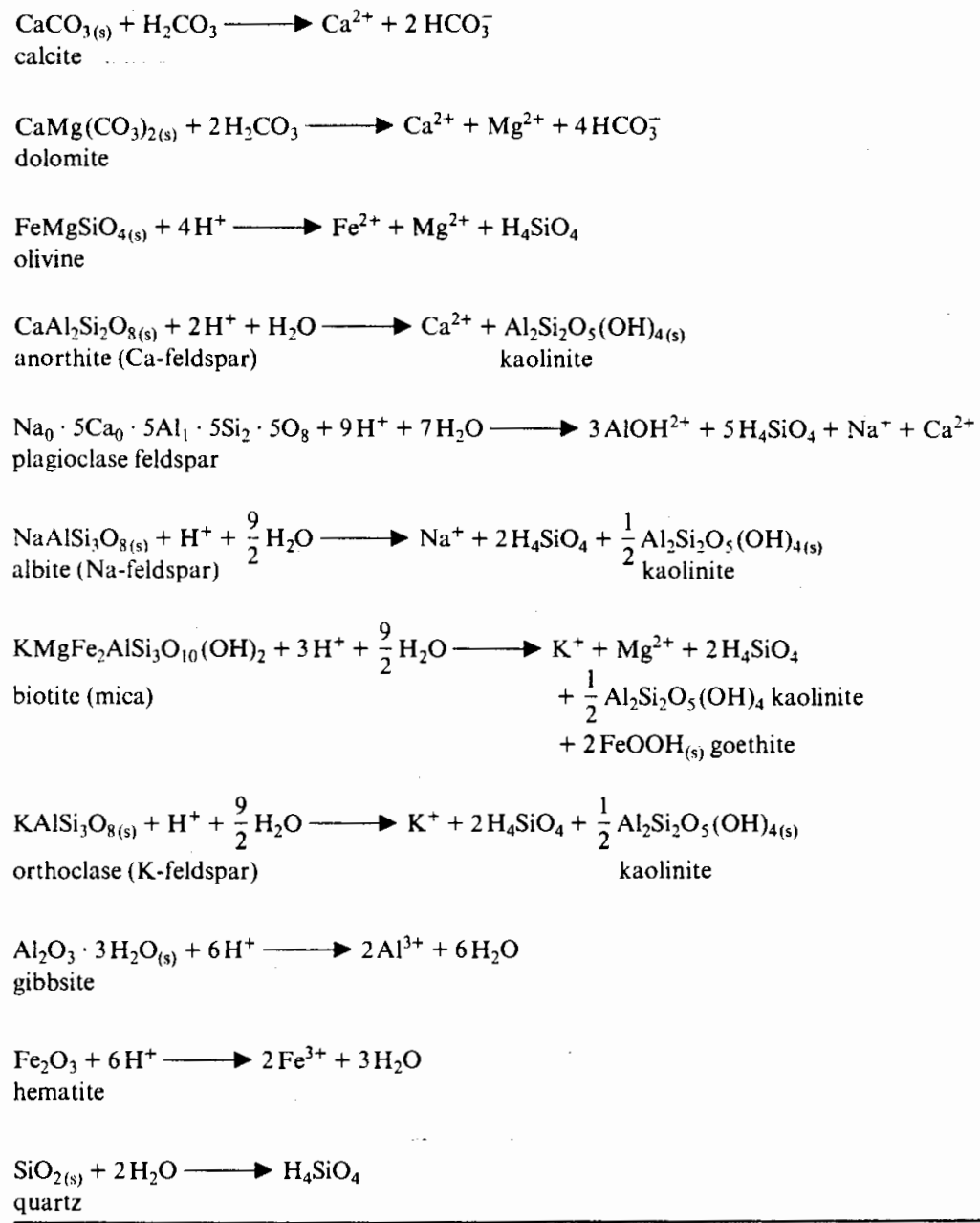

Primary minerals in soils originate from bedrock by mechanical weathering (the breaking of rocks by physical processes, such as the forces involved in freezing and thawing of water in contact with rocks). Many of the areas in the world where the acidification of lakes has been reported is underlain by igneous bedrock [8]. Figure 1 gives the approximate mineral composition of igneous bedrocks [14]. In general, the left hand side of figure 1 corresponds to light-colored rocks of relatively high silica content that are not rapidly weathered. The right hand side corresponds to rocks that are dark in color, low in silica content, and more rapidly weathered. 
(Obsidian) $=m: t e$

Rinyolute
Tuff Brectia

Dacite Andesite Basal

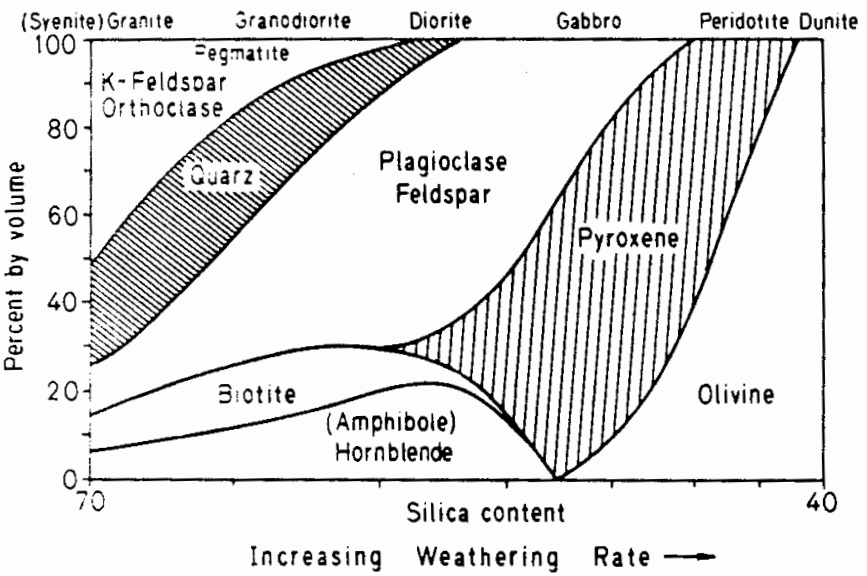

Figure 1. Igncous rock mineral composition and weatherability (modified from Press and Sieves [14]).

A key parameter which determines the rate of chemical weathering of the silicate minerals is their $\mathrm{Si}: \mathrm{O}$ ratio. Silica and oxygen have an ionic radii ratio of 0.32 . This allows a tetrahedral arrangement with silica in the center of the tetrahedron and four oxygen atoms at the rertices. Aluminum has a similar ionic radius ratio with oxygen 0.38 , and it can substitute for silica to form alumina tetrahedra or in some cases octahedra. If the mineral crystal structure is composed of isolated tetrahedra, in which each $\mathrm{SiO}_{4}$-tetrahedron is bonded separately to metal ions, then dissolution in the presence of water should occur comparatively rapidly. Such is the case for the mineral olivine ( $\mathrm{Mg}$, $\mathrm{Fe})_{2}-\mathrm{SiO}_{+}$. On the other hand, if the silica atoms share oxygen atoms among tetrahedra, then the crystal structure is more polymerized and difficult to dissolve. Sharing oxygen atoms is accomplished in the crystal structure by the formation of rings, chains, double chains, sheets of rings, or other frameworks where oxygen atoms are bonded and shared to more that one silica atom. Thus, olivine and anorthite have $\mathrm{Si}: \mathrm{O}$ ratios of $1: 4$, pyroxenes have ratios of $1: 3$. amphiboles $\sim 4: 11$, albite or sodic-feldspar $3: 8$, kaolinite $2: 5$, and quartz $1: 2$. a decreasing order of weathering rates as expected.

The total acid neutralizing capacity (ANC) of soil (eq/ $/ \mathrm{kg}$ ) can be defined as the total amount of cations or bases present. It is best measured by elemental analysis and expressed in oxide equivalents [15].

$$
\begin{aligned}
\mathrm{ANC}= & 6\left[\mathrm{Al}_{2} \mathrm{O}_{3}\right]+2[\mathrm{CaO}]+2\left[\mathrm{~K}_{2} \mathrm{O}\right]+2\left[\mathrm{Na}_{2} \mathrm{O}\right]+4\left[\mathrm{MnO}_{2}\right] \\
& +2[\mathrm{MnO}]+2[\mathrm{FeO}]-2\left[\mathrm{SO}_{3}\right]-2\left[\mathrm{P}_{2} \mathrm{O}_{5}\right]-[\mathrm{HCl}]
\end{aligned}
$$


Silicate oxide minerals provide most of the ANC of sensitive soils. Sorbed sulfates, phosphates and $\mathrm{HCl}$ provide base neutralizing capacity in the soil and are subtracted in the calculation of total ANC. Iron(III) minerals are not included in equation (4) because of their low solubility at the soil $\mathrm{pH}$ values ( $\mathrm{pH} \mathrm{3-7)}$ of interest. Iron(II) minerals are somewhat more soluble, especially under reducing or anaerobic conditions, but under aerobic conditions, the reduced iron is eventually oxidized to $\mathrm{Fe}^{3+}$ and immobilized.

\subsection{Podsolization}

Acid lakes are found in regions of acid soils - especially podzolic soils. This is true in southern Sweden and Norway and New England [16]. This does not necessarily indicate that acid soils cause lakes to become acidic. Podzolic soils developed over geologic time in response to vegetation and climate in temperate, humid regions. The soils are somewhat light in color, and many of the dark minerals have been leached from the upper soil over geologic time. The amount of precipitation accelerates the leaching of the soil, and vigorously growing vegetation can also speed the process. In the short term, vegetation takes base cations from the soil which accumulate into an aggrading canopy. Because vegetation takes up more cations than anions from the soil as required by stoichiometry, this process acidifies the soil by the release of $\mathrm{H}^{+}$ions into soil solution to balance charge. The ash from forst fires contains the residual bases (oxides of these base cations).

Also, vegetation produces some organic acids (such as oxalic acid) as root-exudates which increases the rate of chemical weathering of minerals. Decaying humus and litter fall (e.g. pine needles) are known to produce organic acids and carbonic acid $\left(\mathrm{CO}_{2}+\mathrm{H}_{2} \mathrm{O}\right)$ which percolate through the soil and accelerate the leaching process. The production rate of hydrogen ion due to these 'natural' processes can be compared to the acid deposition rate $\left(\mathrm{eq} / \mathrm{ha} \cdot \mathrm{yr} \mathrm{H}^{+}\right)$in order to determine which source of acidity predominates. In the few instances where such a calculation has been performed, both natural and anthropogenic sources of acidity were of the same order. However, the recent addition of anthropogenic acid deposition most likely has caused the observed declines in $\mathrm{pH}$ of surface waters below natural conditions. This is particularly true in clear water systems, lacking organics.

There are several factors which affect the rate of chemical weathering in soil solution [17, 18]. These include:

- hydrogen ion activity of the solution

- ligand activities in solution

- dissolved $\mathrm{CO}_{2}$ activity in solution

- temperature of the soil solution

- mineralogy of the soil

- flowrate through the soil

- grain size of the soil particles

For a given silicate mineral, the hydrogen ion attack contributes to the formation of surface-activated complexes which determine the rate of mineral dissolution at $\mathrm{pH} 5$. Also, since mineral dissolution is a surface reaction controlled phenomenon, organic and inorganic ligands (e.g. oxalate, formate, succinate, humic and fulvic acids, fluoride, and sulfate) may form other surface activated complexes which enhance dissolution [19-21]. 
Dissolved carbon dioxide is known to accelerate chemical weathering presumably due to its effects on soil pH and the aggression of $\mathrm{H}_{2} \mathrm{CO}_{3}$. Increases in temperature generally increase the rate of chemical weathering, although the solubility of many minerals (e.g. gibbsite and calcite) increases at lower temperatures. Because mineral dissolution is kinetically controlled, increases in the rate of flow and decreases in the particle size can strongly increase the rate of chemical weathering [17, 20,22,23].

\subsection{Exchangeable and mineral bases}

Figure 2 shows the processes which affect the acid neutralizing capacity of soils. Ion exchange occurs at the surface of clays and organic humus in various soil horizons. The

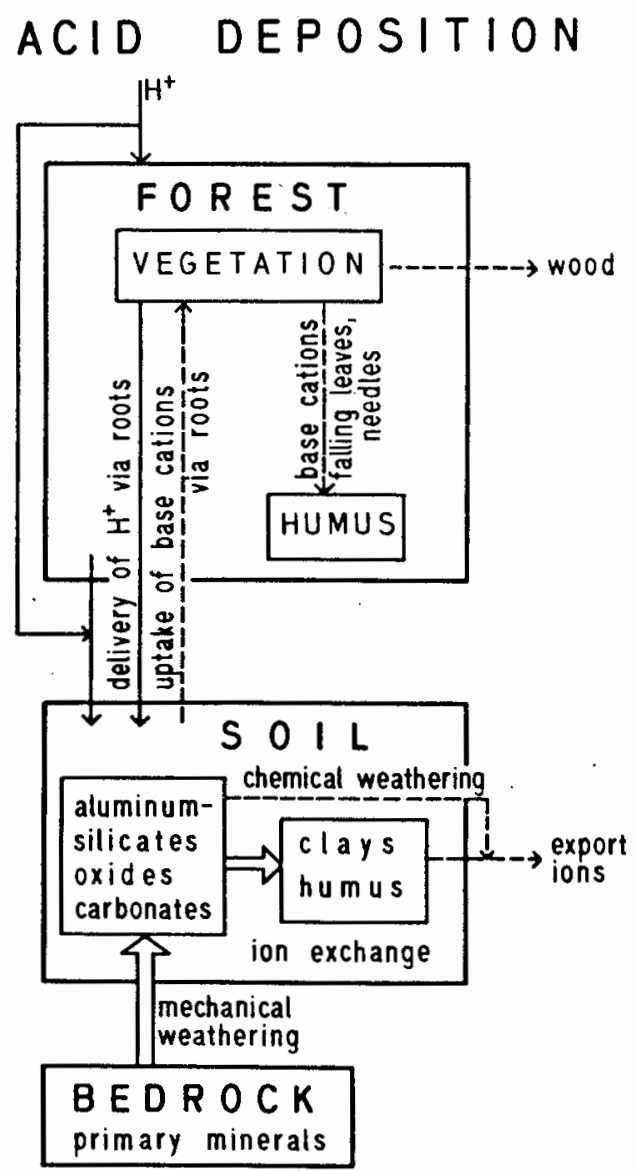

Figure 2. Process affecting the acid-neutralizing capacity of soils (including the exchangeable bases, cation exchange. and mineral bases). $\mathrm{H}^{+}$-ions from acid precipitation and from the release by the roots (of an aggrading forest) react by weathering carbonates, aluminum silicates and oxides and by ion cxchange on clays and humus. Mechanical weathering resupplies weatherable minerals. Lincs drawn out indicate flux of protons; dashed lines show flux of base cations (alkalinity). 
net effect of ion exchange processes is identical to chemical weathering, i.e., hydrogen ions are consumed and basic cations $\left(\mathrm{Ca}^{2+}, \mathrm{Mg}^{2+}, \mathrm{Na}^{+}, \mathrm{K}^{+}\right)$are released. However, the kinetics of ion exchange are rapid relative to those of chemical weathering (on the order of minutes to hours compared to days). In addition, the pool of exchangeable bases is small compared to the total ANC of the soil. Thus there exist two pools of bases in soils: a small pool of exchangeable bases with relatively rapid kinetics and a large pool of mineral bases with the slow kinetics of chemical weathering. If chemical weathering did not replace exchangeable bases in acid soils of temperate regions receiving acidic deposition, the base exchange capacity would be completely diminished over a period of 50-200 years [20].

Soil materials that contain an appreciable proportion of colloidal sized particles (clays and humus) have the capability to exchange ionic constituents on their surfaces. The simplest case of ion exchange is that for a pure diffuse (Gouy) double layer where the specificity of their ions, except their valency, can be neglected. In the discrete site model for ion exchange the exchange reactions occur on discrete (exchange) sites, one ion equivalent per site. Two modes of binding occur: 1) electro-static (development of a diffuse double layer); and 2) formation of (inner sphere) surface complexes, which can explain the differences in selectivity among ions having the same valency [Sposito, 81, 84]. Very specific or extremely selective effects can be observed if inner-sphere complexes are formed, e. g., by the interaction of a proton or metal ion with an oxygen donor group of the surface, or by ligand exchange where ligands (anions or weak acids) displace the $\mathrm{OH}^{-}$ from surface OH-groups. Furthermore, it is important to distinguish between exchange reactions and reactions where the solid- or surface phase changes its composition. Both processes modify the composition of the water. The change in alkalinity resulting from weathering and rock alterations is phenomenologically accompanied by a change of ions in solution; but it must not be mistaken as an ion exchange reaction. The generation of silicic acid in watersheds is one measure of aluminosilicate weathering that is distinctive from ion exchange, although the formation of kaolinite or other clay minerals is a complicating factor which consumes silicic acid and aluminum ions.

In the long run, chemical weathering is the rate-limiting step in the supply of basic cations for export from watersheds. Surface waters are not at chemical equilibrium with regard to common minerals in soils or sediments with the possible exception of amorphous aluminium hydroxide [24]. The chemistry of natural waters is kinetically controlled. Even with regard to ion exchange, the potential for a soil water to be at chemical equilibrium with ion exchange processes is doubtful, especially during precipitation events [25]. The potential for a stream water to be in exchange equilibria with the soil is even less likely due to the maze of flowpaths that contribute to stream flow.

The relative contribution of exchangeable versus mineral bases to cationic export will vary with location in the soil column and with the hydrology and mineralogy of the watershed. In the uppermost soil horizons $\mathrm{O}$ and $\mathrm{A}$, ion exchange processes will predominate. So in very sensitive systems, where water flows mainly through the top $20 \mathrm{~cm}$ of soil, ion exchange processes will predominate and these waters will be acidic or poorly buffered. To the extent that some neutralization of water passing through the upper soil has occurred, it will have been caused by exchange processes. However, the ion exchange complex is largely determined by the chemical weathering of minerals within and below the upper soil horizons. 
Ion exchange equilibria have been used with some success through model calibration of the equilibrium selectivity coefficient [26-29]. These coefficients are not constants and are not thermodynamically based because the activity of the ion on the exchanger (soil matrix) cannot be known. Aluminum-calcium exchange using the Gaines-Thomas [30] approach produces selectivity coefficients that vary over four orders of magnitude in a pure montmorillonite system [31]. Exchangesite ion activities in soil are greatly influenced by the ionic strength of the soil solution, which is a strong function of the moisture content of the soil. The moisture content of the soil varies widely through periods of wetting and drying. In addition, the physical properties of the soil (porosity, surface area, hydraulic conductivity) also change during periods of wetting and drying. For these reasons, it is instructive to consider ionic denudation from a watershed in a 'lumped-parameter' kinetic approach, whereby one looks at the total ion export as a function of the hydrogeologic setting, in order to assess the risk of continued acid deposition.

\section{Hydrology}

There are two major types of hydrologic settings shown in Figure 3 that cause lake waters to be vulnerable to acid deposition: 1) lakes with flashy hydrographs, shallow soils or depth to bedrock, and steep slopes, and 2) precipitation-dominated lakes. Lakes of the first type respond rapidly to precipitation events, both rainfall and snowmelt. They tend to have a relatively short hydraulic residence time, and the reaction time is too short for sufficient chemical weathering to occur as water passes through soils and alluvium on its

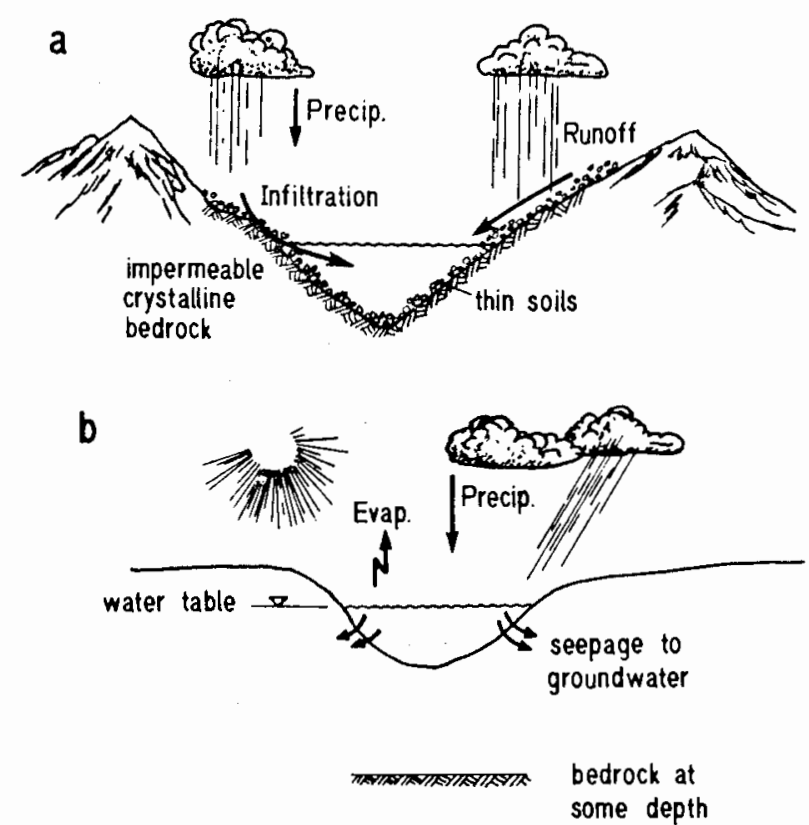

Figure 3. Schematics of two types of hydrologic sensitivity to acid deposition. a: Lakes with rapid response to precipitation events; b: precipitation-doninated lakes. 
way to the lake. Examples of the first type of hydrologic setting are abundant in the literature including lakes in Norway [5, 6], Sweden [4], Switzerland [20], Ontario [9-11], and Hubbard Brook-Falls Brook in New Hampshire [24]. Mountain watersheds often have insufficient time for chemical weathering to fully neutralize acid decomposition. Also, thick and black bog soils with low vertical permeability may cause water to pass only through the upper layer of the soil (the organic 0 -horizon) which precludes neutralization by minerals in the deeper soil. The flowpath as well as the speed that water moves, is important in the rate of neutralization.

The second type of sensitive hydrologic setting has not been as well recognized in the literature. The chemical limnology of precipitation-dominated lakes was first described by Juday and Birge in the 1930's in northern Wisconsin [32]. Eilers et al. [33] have shown that these dilute lakes contain very little alkalinity and dissolved ions. It was possible to categorize the hydrology of the lakes based on a morphologic feature - inlets and outlets. A lake with no permanent inlets or outlets was particularly low in alkalinity and was called a seepage lake. In general, seepage lakes receive most of their water from precipitation falling directly on the surface of the lake, and discharge of water is predominantly as evaporation from the surface and, to a lesser extent, seepage into the groundwater. Lakes with only an inlet and no outlets are termed inflow lakes; lakes with permanent inlets and outlets are drainage lakes; and lakes with no inlets but having at least one permanent outlet are called spring lakes. The two most important factors influencing the chemical neutralization rate of lake waters are the hydrologic setting and the mineralogy of the till and bedrock. Lakes with extreme sensitivity to acidic deposition usually have both types of characteristics.

\section{Kinetics}

The surfaces of aluminosilicate minerals in the presence of water are characterized by amphoteric surface hydroxyl groups. The surface $\mathrm{OH}^{-}$group has a complex-forming O-donor atom that coordinates with $\mathrm{H}^{+}$and metal ions [34-36]. The underlying aluminum ion in the surface tetrahedra of the oxide and the base cation are subject to coordination with $\mathrm{OH}^{-}$-groups, which in turn weakens the bond to their structural oxygen atoms. Detachment of an activated complex removes the coordination complex and renews the surface for further hydrolysis, protonation and dissolution. In addition, the underlying central metal ions can exchange their structural $\mathrm{OH}^{-}$-ions for other ligands (e.g. organic anions) to form a strong surface coordination complex which can facilitate dissolution.

\subsection{Laboratory studies}

Seminal studies of mineral dissolution in the laboratory have reported 'parabolic' dissolution rates (linear functions of the square root of time), a result consistent with diffusional transport-limited kinetics [37-42]. Recently, the work of Berner and others [43-47, 19] has suggested that parabolic dissolution kinetics are an artifact of mineral grinding. Disrupted grain surfaces and ultrafine mineral particles dissolve initially at a high rate. Dissolution rates are actually linear in time. An initial incongruent dissolution may last over a few hours in which a thin cation-depleted layer is hypothesized (from 2 to $17 \AA$ on 
the surface of the crystal [47]. Basic cations $\left(\mathrm{Ca}^{2+}, \mathrm{Mg}^{2+}, \mathrm{K}^{+}, \mathrm{Na}^{+}\right)$are depleted preferentially to $\mathrm{Si}$ and $\mathrm{Al}$. This period is followed by a relatively long period (days to weeks) of subsequent congruent dissolution.

Scanning electron micrographs and X-ray photoelectron spectroscopy have allowed observations of mineral surfaces during hydrolysis. While secondary mineral formation is sometimes observed, a coating of the primary mineral surface does not occur. Dissolution reactions occur preferentially along crystal defects, screw dislocations, and etch pits. These results have been reported for a wide range of minerals including microcline, feldspars, augite, diopside, hypersthene, and hornblende [43-46, 52].

Prior to the work reported in table 2, Correns [17] discussed the importance of hydrogen ion attack on minerals (hydrolysis). Fractional order dissolutions with hydrogen ion activity can be estimated from Corren's data [18] for the silicate minerals olivine $\left((\mathrm{Fe}, \mathrm{Mg})_{2} \mathrm{SiO}_{4}\right), \quad \mathrm{K}$-feldspar $\left(\mathrm{KAlSi}_{3} \mathrm{O}_{8}\right), \quad$ muscovite $\quad\left(\mathrm{KAl}_{3} \mathrm{Si}_{3} \mathrm{O}_{10}(\mathrm{OH})_{2}\right)$, albite $\left(\mathrm{NaAlSi}_{3} \mathrm{O}_{8}\right)$, and leucite $\left(\mathrm{KAISi}_{2} \mathrm{O}_{6}\right)$.

A very important result of recent laboratory studies has been the fractional order dependence of mineral dissolution on bulk phase hydrogen ion activity. If the dissolution reaction is controlled by hydrogen ion diffusion through a thin liquid film or residue layer, one would expect a first order dependence on $\left\{\mathrm{H}^{+}\right\}$. If the dissolution reaction is controlled by some other factor such as surface area alone, then the dependence on hydrogen ion activity should be zero order. Rather, the dependence has been fractional order in a wide variety of studies, indicating a surface reaction controlled dissolution.

Table 2. Reaction order for the rate law for the dissolution of minerals.

\begin{tabular}{lllll}
\hline Mineral & Formula & Solution & Reaction Order & Ref. \\
\hline Dolomite & $(\mathrm{Ca}, \mathrm{Mg}) \mathrm{CO}_{3}$ & $\mathrm{HCl}$ & $\left\{\mathrm{H}^{+}\right\}^{0.5}$ & {$[48]$} \\
Bronzite & $(\mathrm{Mg}, \mathrm{Ca}) \mathrm{SiO}_{3}$ & $\mathrm{HCl}$ & $\left\{\mathrm{H}^{+}\right\}^{0.5}$ & {$[49]$} \\
Enstatite & $\mathrm{MgSiO}_{3}$ & $\mathrm{HCl}$ & $\left\{\mathrm{H}^{+}\right\}^{0.8}$ & {$[47]$} \\
Diopside & $\mathrm{CaMgSi}_{2} \mathrm{O}_{6}$ & $\mathrm{HCl}$ & $\left\{\mathrm{H}^{+}\right\}^{0.7}$ & {$[47]$} \\
K-feldspar & $\mathrm{KAlSi}_{3} \mathrm{O}_{8}$ & $\mathrm{Buffer}$ & $\left\{\mathrm{H}^{+}\right\}^{0.33}$ & {$[41]$} \\
Iron hydroxide & $\mathrm{Fe}(\mathrm{OH})_{3}-\mathrm{Gel}$ & Various acids & $\left\{\mathrm{H}^{+}\right\}^{0.48}$ & {$[50]$} \\
Aluminum oxide & $\delta-\mathrm{Al}_{2} \mathrm{O}_{3}$ & $\mathrm{HCl}$ & $\left\{\mathrm{H}^{+}\right\}^{0.4}$ & {$[19]$} \\
Gibbsite & $\mathrm{Al}(\mathrm{OH})_{3}$ & $\mathrm{HNO}_{3}$ & $\left\{\mathrm{H}^{+}\right\}^{0.7}$ & {$[51]$} \\
\hline
\end{tabular}

\subsection{Kinetics of mineral dissolution}

The dependency of mineral weathering on hydrogen ion activity in solution can be demonstrated using surface coordination chemistry as in equations (5) and (6) below.

$$
\begin{aligned}
& \exists-\mathrm{OH}+\mathrm{H}^{+} \underset{\text { fast }}{\longrightarrow} \exists-\mathrm{OH}_{2}^{+} \\
& \exists-\mathrm{OH}_{2}^{+} \underset{\text { slow }}{\longrightarrow} \mathrm{Me} \cdot\left(\mathrm{H}_{2} \mathrm{O}\right)_{\mathrm{x}}^{2^{+}}+\exists-
\end{aligned}
$$

where

$$
\begin{aligned}
& \exists-\mathrm{OH}=\text { hydrous metal }(\mathrm{Al}, \mathrm{Si}, \mathrm{Fe}, \text { etc.) oxide surface with a functional } \mathrm{OH} \text { group } \\
& \exists-\mathrm{OH}_{2}^{-}=\text {protonated surface group }
\end{aligned}
$$


The dissolution rate is proportional to the degree of protonation of the surface to the power of the central metal ion valence, following stoichiometry.

$$
\text { Rate } \propto\left\{\exists-\mathrm{OH}_{2}^{+}\right\}^{z}
$$

The degree of surface protonation becomes saturated with high concentrations of hydrogen ions in bulk solution, following a Langmuir-type adsorption isotherm. If the logarithm of the degree of surface protonation is plotted versus $\mathrm{pH}$ of the bulk solution (Freundlich isotherm), the middle portion of the plot is of fractional order, $\mathrm{n}<1$.

$$
\log \left\{\exists-\mathrm{OH}_{2}^{+}\right\}=\mathrm{n} \log \left\{\mathrm{H}^{+}\right\}+\log \mathrm{K}_{\mathrm{F}}
$$

where $\mathrm{n}=$ slope of Freundlich isotherm

$\mathrm{K}_{\mathrm{F}}=$ intercept of Freundlich isotherm

By substituting equation (8) into (7), it is possible to express the rate of mineral dissolution in terms of the hydrogen ion concentration in bulk solution.

$$
\text { Rate } \propto\left\{\mathrm{H}^{+}\right\}^{\mathrm{m}}
$$

in which $m=n \cdot z$, fractional order dissolution rate. For aluminium oxide dissolution, Stumm et al. [19] have shown that $m=0.4$ (fractional order), $n=0.13$, and $z=3.1$ (approximately the valence of $\mathrm{Al}^{3+}$ ). See figure 4. In addition to theoretical arguments, experimental evidence exists to validate that equation 9 is approxiate for a wide variety of minerals (table 2).

But hydrogen ion attack on minerals (hydrolysis) is not the only means of mineral dissolution. Other ligands, such as organics in soil solution, are known to accelerate the dissolution of minerals. This process, too, can be viewed as a surface coordination reaction with the following mechanism. For a hypothetical diprotic acid $\left(\mathrm{H}_{2} \mathrm{~A}\right)$ and a central metal ion $(\mathrm{Me})$ of valence $\mathrm{z}$ :

$$
\begin{aligned}
& \exists-\mathrm{OH}+\mathrm{H}_{2} \mathrm{~A} \underset{\text { fast }}{\longrightarrow} \exists-\mathrm{AH}+\mathrm{H}_{2} \mathrm{O} \\
& \exists-\mathrm{AH} \underset{\text { slow }}{\longrightarrow} \mathrm{Me}(\mathrm{AH})^{(\mathrm{z}-1)+}+\exists-
\end{aligned}
$$

The rate-determining step is detachment of the coordination complex at the surface, and the rate of dissolution is proportional to the degree of ligand binding on the mineral surface of the concentration of ligand in bulk solution.

$$
\text { Rate }=k_{1}\left\{\exists-\mathrm{A}^{-}\right\} \propto\left[\mathrm{HA}^{-}\right]
$$

Two types of mineral dissolution (hydrolysis and ligand at tack) give rise to mixed kinetics overall. These kinetics are: (19)

$$
\text { Rate }=\mathrm{k}_{1}\left\{\exists-\mathrm{OH}_{2}^{+}\right\}^{\mathrm{r}}+\mathrm{k}_{2}\left\{\exists-\mathrm{A}^{-}\right\}
$$




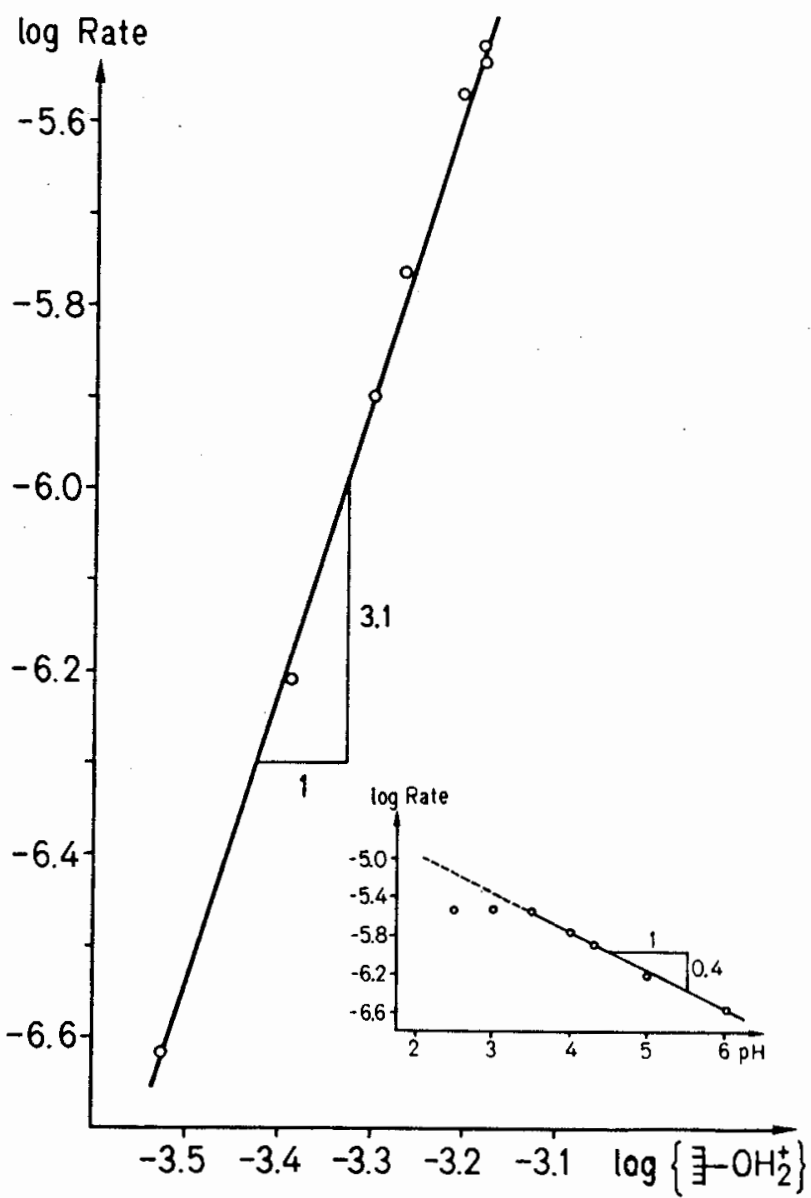

Figure 4. Log rate of aluminum oxide dissolution versus the concentration of surface protons indicating a surface reaction controlled dissolution [19]. Log rate aluminum oxide dissolution versus $\mathrm{pH}$ showing fractional order kinetics (see inset).

It is well known that organic complex-formers, e.g., simple organic acids (citric, oxalic, tartaric, salicylic) formed by microorganisms in soils and humic or fulvic acids 'solubilize' mineral iron(III) and aluminium. These complex formers not only increase the solubility of these minerals, but they also are able to form chelates on their hydrous oxide surfaces $[19,21,35,36]$ and thus, in turn catalyze the dissolution of oxides and aluminum silicates. The downward vertical displacement of $\mathrm{Al}$ and $\mathrm{Fe}$, as it is observed in the podsolization of soils can be accounted for by considering the effect of $\mathrm{pH}$ and of complex formers on both the solubility equilibria and the dissolution rates. Figure 5 illustrates the calculated effects that acidity $(\mathrm{pH})$ and organic complex-formers (oxalate is used as an example) exert in enhancing the dissolution of iron(III) and $\mathrm{Al}(\mathrm{III})$.

In a similar way as organic bidentate complex formers form inner-sphere complexes with $\mathrm{Al}$ and $\mathrm{Fe}$ on the surface of oxides (19), the sulfate ion may form a strong complex with 

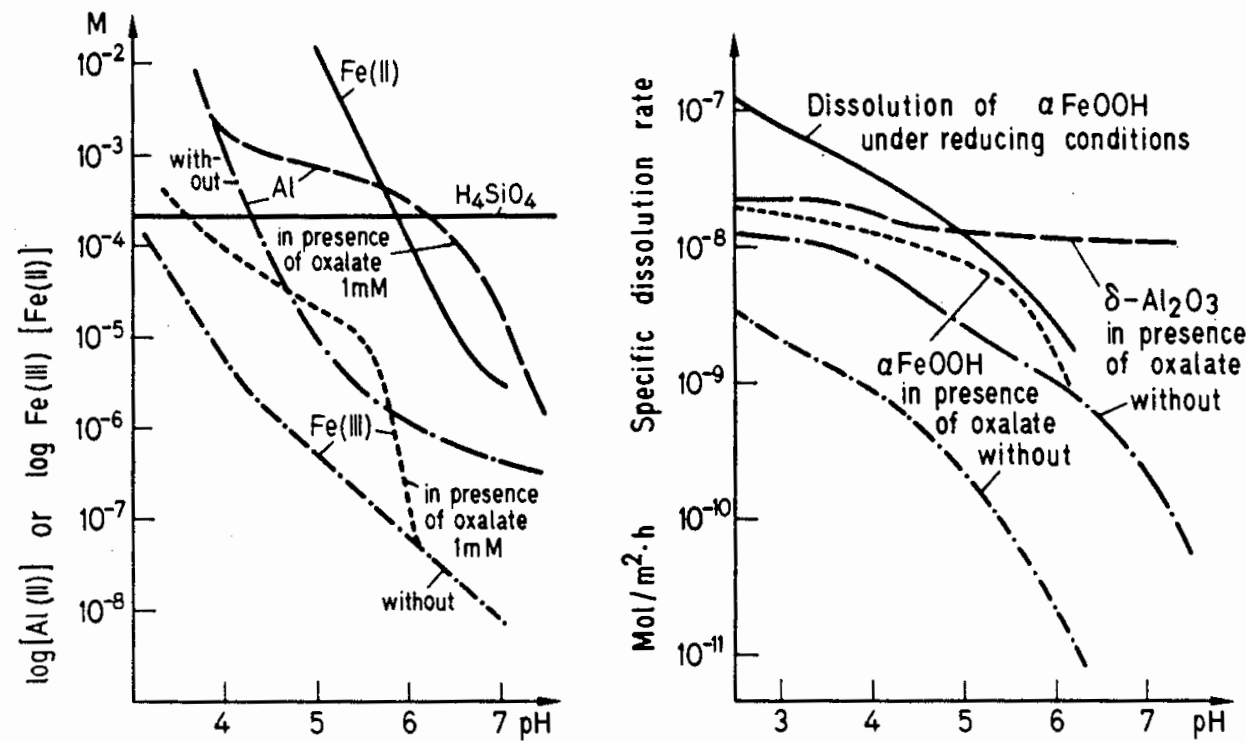

Figure 5. Effect of acidity and organic complex former on the dissolution of $\mathrm{Al}$ and $\mathrm{Fe}$ (modified from $\mathrm{B}$. Zinder and W. Stumm, Chimia 39, 280-288 (1985). In the podsolization of soils Al and Fe become solubilized and displaced downwards in the soil column. Equilibrium solubility and rates of dissolution are influenced markedly by low $\mathrm{pH}$ and complex formers (oxalate, typically excreted by microorganisms in the rhizosphere, is used as a model substance). In case of iron, lowering of the redox potential to $E_{\mathrm{H}} 410 \mathrm{mV}(\mathrm{pH}=4-7)$ causes reduction of

$\mathrm{Fe}(\mathrm{III})$ to soluble $\mathrm{Fe}$ (II). Further down in the soil column where $\mathrm{pH}$ becomes more neutral and more aerobic conditions prevail the oxides or hydroxides that are now less soluble become deposited:

$\mathrm{Al}-\mathrm{Ox}+\mathrm{H}_{2} \mathrm{O} \leftrightarrows \mathrm{AlOH}+\mathrm{Ox}^{2-}+\mathrm{H}^{+}$. The rates in figure 5 have been calculated with the rate laws [19], assuming a surface coverage of $10^{-6} \mathrm{~mol} \mathrm{~m}^{-2}$ oxalate.

the central metal ion. Thus the complex may become activated and may serve as a good detachment group, enhancing mineral dissolution. For a central metal ion with valence +2 :

$$
\begin{aligned}
& \mathrm{SO}_{a}^{2-}+\exists_{-\mathrm{OH}}^{-\mathrm{OH}} \underset{\mathrm{fast}}{\mathrm{Z}^{\prime}} \mathrm{O}_{\mathrm{O}_{\mathrm{O}}^{\prime}}^{\mathrm{O}}+2 \mathrm{OH}^{-} \\
& \exists_{-O^{\prime}}^{-\mathrm{S}_{\mathrm{O}}^{\prime}} \underset{\text { slow }}{\mathrm{O}} \mathrm{Me}\left(\mathrm{SO}_{4}\right)_{(\mathrm{aq})}^{0}+\exists_{-\mathrm{OH}}^{-\mathrm{OH}}
\end{aligned}
$$

The implications of equations (14) and (15) are that sulfate ion may speed the rate of chemical weathering in addition to the hydrogen ion attack of $\mathrm{H}_{2} \mathrm{SO}_{4}$. This requires that soils which are well buffered with respect to $\mathrm{pH}$ by $\mathrm{CO}_{2}$ supersaturation and by organic acids may still be leached by sulfate. Such soils would not be much affected by acid precipitation except by the leaching action of sulfate. 


\section{Chemical weathering and acid rain}

Figure 6 demonstrates the effects of chemical weathering in a mountain valley of the southern Swiss Alps. There, nature provides an interesting weathering experiment which is relatively free of competing acid-base or redox reactions, since there is little soil or vegetation at an altitude of $2100-2500 \mathrm{~m}$. Chemical weathering is the predominant process which modifies the chemistry of the acid snowmelt water as it runs down the valley. Initially, the predominant cation in snowmelt water was hydrogen ion, but it was neutralized rapidly, and calcium from chemical weathering became the dominant cation. Aluminium ions increased early in the progression (while the $\mathrm{pH}$ was less than 5.0), but then $\mathrm{Al}^{3+}$ decreased, possibly due to gibbsite precipitation. The alkalinity produced (including $\mathrm{H}^{+}$-ion consumption) was equal to the cation production as demonstrated by the equations of table 1. Sulfate from precipitation was roughly conservative, while $\mathrm{HCO}_{3}^{-}$increased as a result of $\mathrm{CO}_{2}+\mathrm{OH}^{-}$generated in the weathering process.

The geology of the area in the vicinity of Lake Cristallina is crystalline rock of the Permo-Carboniferous period, with granite gneiss and mica schist predominating. In an
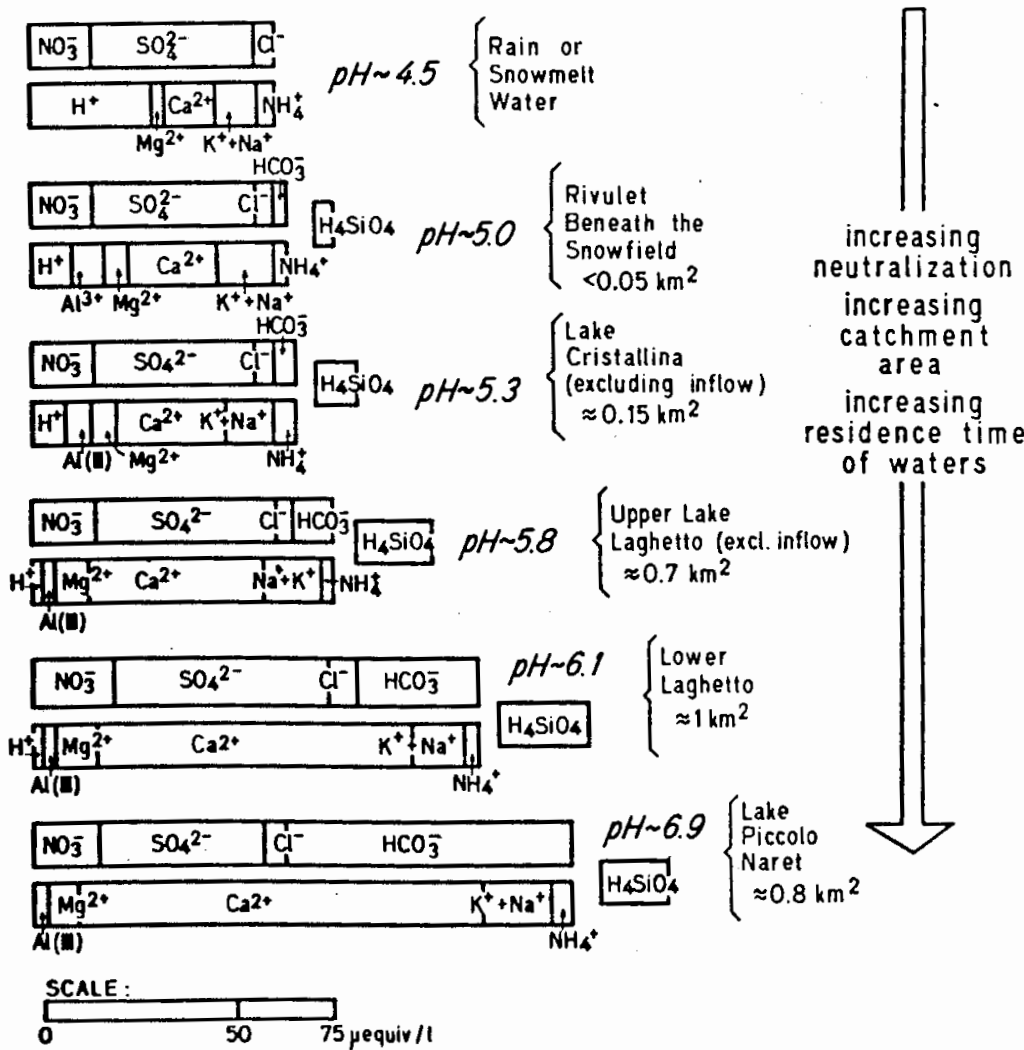

Figure 6. Chemical weathering and dissolution of minerals proceeding down a mountain stream (Maggia Valley, Tessin, Switzerland) [20]. 
adjacent eatchment area, there is a bedrock unit called 'Bündnerschiefer' which is of the Jurassic-Cretaceous age and is composed of schist and slate that is known to contain some calcareous minerals, and also there is a Triassic unit with some dolomite. From a 'back-calculation' using measured water chemistry in table 3 , it is possible to show that plagioclase, biotite and calcium carbonate $\left(\mathrm{CaCO}_{3}\right)$ or anorthite $\left(\mathrm{CaAl}_{2} \mathrm{Si}_{2} \mathrm{O}_{8}\right)$ must be weathering in the catchment area. Calcium could be derived as wind-blown dust from long range transport of nearby dolomites and Bündnerschiefer, or it could be by preferential dissolution of anorthite from the granite gneiss and renewal of the rock surface by mechanical weathering. Table 3 shows how rock weathering products contribute to lake chemistry assuming that the mineralogy is well characterized (after the seminal work by Garrels and Christ and others [53-59]. Different assumptions can be made to arrive at a formula for rock-weathering products such as table 3 . It is impossible to distinguish between the weathering of calcite versus anorthite. However, chemical weathering accounts for the observed increase in cations and alkalinity, and the alkalinity produced is exactly balanced by the cations produced (and the hydrogen ions consumed).

The role that acid rain plays in the chemistry of dilute. sensitive waters is still a matter of scientific debate [60-70]. From a research standpoint. it is necessary to instrument a 'calibrated' watershed site and obtain an accurate 1) flow balance, 2) precipitation record and ion analysis, 3) output from the watershed and ion analysis, 4) measurement of dry $\mathrm{SO}_{2}$ and $\mathrm{NO}_{x}$ deposition if they are important, and 5) audit of internal processes such as afforestation, sulfide mineral oxidation, and nonsteady state sea-salt effects. Seldom have such intensive studies been undertaken, but there are a few cases where complete budgets have been attempted on watersheds [71-73] and forest soils $[74,75]$.

One difficult problem is estimating the weathering rate which should be used in mathematical models of specific catchments. If the mineralogy is known for the catchment, an

Table 3. Lake Cristallina: Possible reactions for establishing the chemical composition of Lake Cristallina based on the concentration of ions in acid precipitation and the bedrock composition of granitic gneiss $(25 \%$ plagioclase, $15 \%$ biotite, $30 \%$ quartz, $20 \% \mathrm{~K}$-feldspar, $10 \%$ epidote).

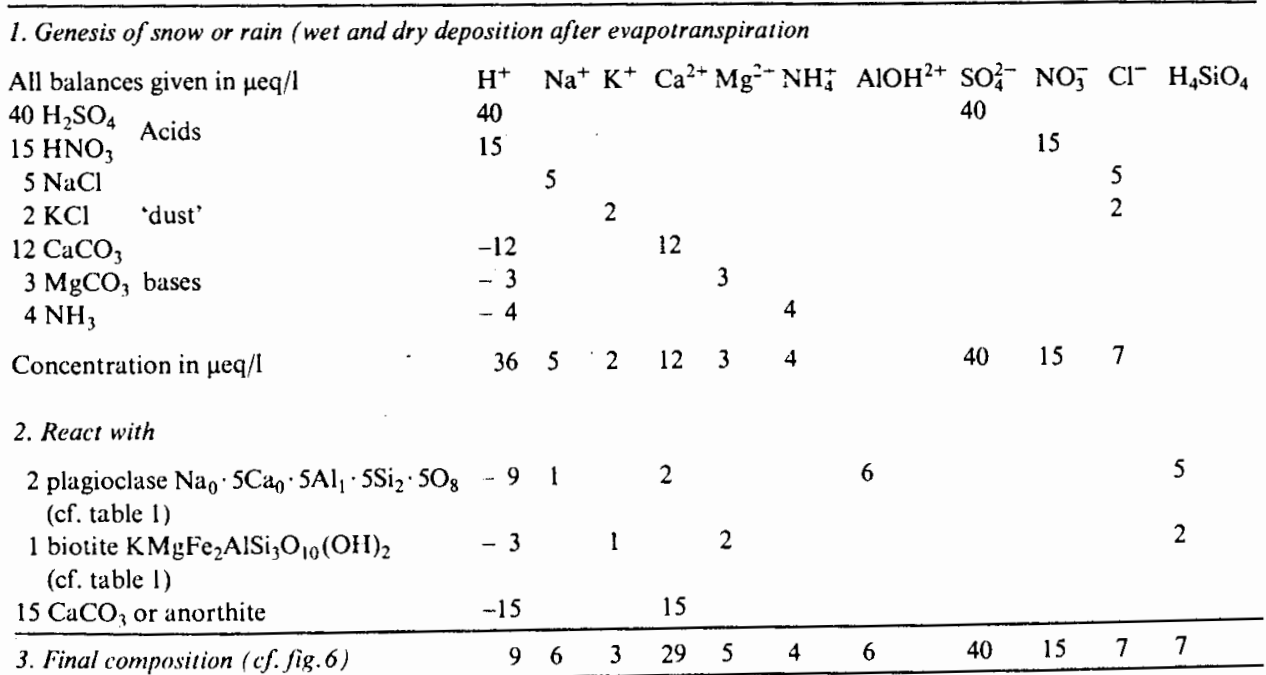


Table 4. Comparison of laboratory and lield weathering rates.

\begin{tabular}{|c|c|c|c|c|c|c|}
\hline Reference & Mineral & $\begin{array}{l}\text { Laboratory } \\
\text { weathering rate } \\
\text { mol m}{ }^{-2} \mathrm{~s}^{-1}\end{array}$ & $\begin{array}{l}\text { Ficld-estimated } \\
\text { weathering rate } \\
\text { mol m} \mathrm{m}^{-2} \mathrm{~s}^{-1}\end{array}$ & $\begin{array}{l}\text { Field-measured } \\
\text { cation export } \\
\text { mol hat } \mathrm{yr}^{-1}\end{array}$ & Cation/s & Noles \\
\hline [76] & Plag. (oligoclase) & $1.7 \times 10^{-12}$ & $1 \times 10^{-14}$ & 210 & $\mathrm{Na}^{+}$ & Trnavka River Basin (CZ) \\
\hline \multirow[t]{3}{*}{ [77] } & Plag. (oligoclase) & $1.7 \times 10^{-12}$ & $8.9 \times 10^{-13}$ & 455 & $\mathrm{Na}^{+}, \mathrm{Ca}^{2+}$ & Coweeta Watershed, N.C. (USA) \\
\hline & Almandine & & $3.8 \times 10^{-12}$ & 300 & $\mathrm{Mg}^{2+}, \mathrm{Ca}^{2+}$ & \\
\hline & Biotite & & $1.2 \times 10^{-13}$ & 350 & $\mathrm{~K}^{+}, \mathrm{Mg}^{2+}$ & \\
\hline \multirow[t]{2}{*}{ [78] } & Plag. (bytownite) & 1) $1.7 \times 10^{-12}$ & $3 \times 10^{-13}$ & 250 & $\mathrm{Na}^{+}$ & Filson Creek, Minn. (USA) \\
\hline & Olivine & 2) $7 \times 10^{-12}$ & $1 \times 10^{-11}$ & 280 & $\mathrm{Mg}^{2+}$ & $\begin{array}{l}\text { Assumptions: } 50 \mathrm{~cm} \text { of satd. regolith, } \\
5 \mathrm{~m}^{2} / \mathrm{g} \text { surface area of mineral grains, } \\
\text { at measured abundance }\end{array}$ \\
\hline \multirow[t]{2}{*}{ This study } & Plag. (oligoclase) & 1) $1.7 \times 10^{-12}$ & $4 \times 10^{-13}$ & 32 & $\mathrm{Na}^{+}$ & Lake Cristallina (CH) \\
\hline & Biotite & & $3 \times 10^{-13}$ & 16 & $\mathrm{~K}^{+}, \mathrm{Mg}^{2+}$ & $\begin{array}{l}\text { Assumption: } 10 \mathrm{~cm} \text { of satd. regolith, } \\
5 \mathrm{~m}^{2} / \mathrm{g} \text { surface area of mineral grains } \\
\text { measured }\end{array}$ \\
\hline \multirow[t]{3}{*}{ [79] } & $\delta-\mathrm{Al}_{2} \mathrm{O}_{3}$ & $1.9 \times 10^{-12}$ & & & $\mathrm{Al}^{3+}$ & Aluminum dissolution rates in the \\
\hline & Kaolinite & $5.0 \times 10^{-13}$ & & & $\mathrm{Al}^{3+}$ & laboratory for comparison \\
\hline & Muscovite & $4.4 \times 10^{-13}$ & & & $\mathrm{Al}^{3+}$ & \\
\hline
\end{tabular}

1) Rate determined in the laboratory by Busenberg and Clemency [80] at pH 4 .

2) Rate determined in the laboratory on beach sand by Grandstaff [81] at pH 4.5 . 
initial estimate can be obtained based on laboratory studies and the abundance of weatherable minerals in the soil and bedrock. Weatherable minerals in crystalline areas affected by acid rain are usually plagioclase feldspars, amphiboles (e. g. hornblende and biotite), silicates (e.g. olivine), and pyroxenes. Table 4 is a comparison between some weathering rates determined in the laboratory on pure minerals and estimated weathering rates from catchment studies. The estimates of weathering rates in the field depend on assumptions of the saturated groundwater zone through which water flows to the discharge point and on the surface area of weatherable mineral in the soil and bedrock which reacts. Even with such uncertainty, the field-estimated weathering rates are within an order of magnitude of the laboratory rates except for that by Paces [76].

Generally, the field-estimated weathering rates are somewhat smaller than the laboratory measurements, perhaps due to a smaller number of reactive sites per square meter of surface area for highly weathered minerals. This could be attributed to hydrous oxide coatings on the mineral surface in the field environs or a smaller number of dislocations, edges, and etch pits on weathered minerals.

From the literature, we know that acid deposition can contribute $\mathrm{H}^{-}$-ions on the order of $1000 \mathrm{eq} / \mathrm{ha} \cdot \mathrm{yr}(\mathrm{pH} 4$ precipitation and $100 \mathrm{~cm} /$ year precipitation). but nitrification of gaseous ammonia in Holland can contribute $7200 \mathrm{eq} / \mathrm{ha} \cdot \mathrm{yr}$ [75]: aggrading forest biomass can easily account for $1000 \mathrm{eq} / \mathrm{ha} \cdot \mathrm{yr}[71,74]$ and whole-tree harvesting practices can account for much more; sulfide mineral oxidation can be extremely large with a limiting value of acid mine drainage in the $10^{4} \mathrm{eq} / \mathrm{ha} \cdot \mathrm{yr}$ [82. 83]. Ion exchange processes and the 'salt-effect' in soils can acidify coastal waters [67]. Acid soils do not acidify lakes per se. They are an indication that readily weatherable minerals are lacking in the watershed. The processes which produce acidity must be assessed on a case-by-case basis. These include $\mathrm{H}^{+}$-production by forest growth and harvesting practices. ammonia oxidation in the watershed, sulfide mineral oxidation (if present). and humus decomposition and production of organic acids. Alkalizing processes include chemical weathering, sulfate reduction, sulfate sorption in soils, nitrate assimilation by algae. and denitrification. Sulfate sorption is known to be an important process in old. non-glaciated soils of the southeastern US $[29,74]$. Sulfate reduction and denitrification at the sediment-water interface occur in lakes of long detention times ( $>1$ year) and have been proven to contribute to the alkalinity production in the watershed [84].

In sensitive crystalline regions of the northern temperate zone. where the acidity of precipitation is small ( $\mathrm{pH} 4.8-5.6$ ), all of these processes result in lake alkalinity (ANC) concentrations greater than zero and chemical weathering rates ( = alkalinity production rates) of $200-2000 \mathrm{eq} / \mathrm{ha} \cdot \mathrm{yr}$. There are no acid lakes because the net effect of all alkalizing processes minus all acidifying processes still yields a small net alkalinity and cation export.

\section{Simplified model and results}

A simplified mass balance model for lakes receiving acid deposition in sensitive regions was first reported in Stumm et al. [1]. It is based on the principle of continuity for alkalinity and is a steady state formulation. It assumes that chemical weathering (and ion exchange) is the major process in most sensitive watersheds which is serving to neutralize acid deposition. 
A mass balance for alkalinity in the lake is:

$$
\mathrm{V} \frac{\mathrm{d}(\mathrm{Alk})}{\mathrm{dt}}=-\mathrm{IL}_{\mathrm{acv}}-\mathrm{Q}(\mathrm{Alk})+\mathrm{IW} /(\mathrm{R} \cdot 0.1)
$$

where

$\mathrm{V}=$ water volume of the lake, $\mathrm{m}^{3}$

Alk $=$ alkalinity concentration, $\mu \mathrm{eq} \mathrm{l}^{-1}$

$\mathrm{t}=$ time, $\mathrm{yr}$

I $=$ inflow volume per time, $\mathrm{m}^{3} / \mathrm{yr}$

$L_{\text {acy }}=$ total acidity of precipitation (dry + wet), $\mu$ eq $1^{-1}$

$\mathrm{Q}=$ outflow or seepage $\mathrm{rate}, \mathrm{m}^{3} / \mathrm{yr}$

$\mathrm{W}$ = weathering (neutralization) rate, $\mathrm{eq} / \mathrm{ha} \cdot \mathrm{yr}$

$\mathrm{R}=$ precipitation rate. $\mathrm{cm} / \mathrm{yr}$

$0.1=$ units conversion factor

The steady state solution to the equation is:

$$
(A l k)=-\frac{I}{Q} L_{2: s}+\frac{I W}{Q R(0.1)}
$$

which includes an acidity contribution to the lake by acid deposition and an alkalinity input due to weathering and ion exchange within the watershed.

An expression for chemical weathering which is analogous to equation (13) is:

$$
\mathrm{W}=\mathrm{k}_{\mathrm{h}}\left\{\frac{\mathrm{L}_{3 \mathrm{si}}}{\mathrm{L}_{\mathrm{rci}}}\right\}^{\mathrm{m}}+\mathrm{K}_{0}
$$

where

$\mathrm{W}=$ chemical weathering rate, eq/ha $\cdot \mathrm{yr}$

$\mathrm{L}_{\mathrm{rer}}=$ reference acidity concentration, $\mu$ eq $1^{-1}$

$\mathrm{k}_{\mathrm{h}}=$ rate constant for acid hydrolysis, eq/ha $\cdot \mathrm{yr}$

$\mathrm{m}=$ fractional order constant

$\mathrm{k}_{0}=$ rate constant in the absence of free acidity (due to $\mathrm{CO}_{2}$ and ligand weathering), $\mathrm{eq} / \mathrm{ha} \cdot \mathrm{yr}$

Equation (18) is consistent with observations of lakes across depositional gradients in the US Upper Midwest [85] and Canada [86], where the output of cations is 3-4 times greater among similar watersheds receiving 5-10 times more strong acid. Equation (18) presumes that flow of water in sensitive watersheds is rather shallow through the soil and alluvium such that weathering rates would be affected by precipitation acidity and possibly the mobile sulfate anion.

By substitution for $W$ from equation (18) into equation (17), one arrives at a final cquation for lake alkalinity concentration as a function of precipitation acidity.

$$
A l k=\frac{1}{Q}\left[\frac{k_{h}\left\{\frac{L_{a c y}}{L_{r c i}}\right\}^{m}+k_{0}}{R(0.1)}-L_{a c y}\right]
$$


Equation (19) indicates that the alkalinity in very sensitive watersheds is a function of the weathering (and ion exchange) products minus the total acidity of precipitation, concentrated by an evapotranspiration factor $(\mathrm{I} / \mathrm{Q})$.

Figure 7 is a plot of equation (19). The most sensitive lakes in northern temperature regions affected by acid rain have chemical neutralization rates of $\sim 200-500 \mathrm{eq} / \mathrm{ha} \cdot \mathrm{yr}$. Some sensitive lakes from intensively studied watersheds are shown as examples on figure 7A. These lakes occupy a very narrow band of extreme sensitivity in the portion of figure 7A between the dashed lines $\mathrm{W} \sim 200$ and $W \sim 1000 \mathrm{eq} / \mathrm{ha} \cdot \mathrm{yr}$. A hypothetical lake with an initial alkalinity of $25 \mu \mathrm{eq} \mathrm{l}^{-1}$ would follow the reaction progress line beginning at point $\mathrm{P}$ of figure 7A, according to equation (19). This reaction progress line is consistent with the pattern of lakes at different depositions in sensitive regions under steady state conditions. The titration progress and fractional order weathering (neutralization) rate is given by figure $7 \mathrm{~B}$.

In the titration curve of figure 7B, the curve goes through an inflection point at an acid added concentration of $\sim 80 \mu \mathrm{eq} / 1^{-1}$, i.e. an acidity of precipitation of $40 \mu \mathrm{eq} / /^{-1}\left(\mathrm{~L}_{\mathrm{acy}}\right)$ and a concentration factor $(\mathrm{I} / \mathrm{Q})$ of two. This corresponds to $\mathrm{pH}$ of precipitation of 4.4. Some

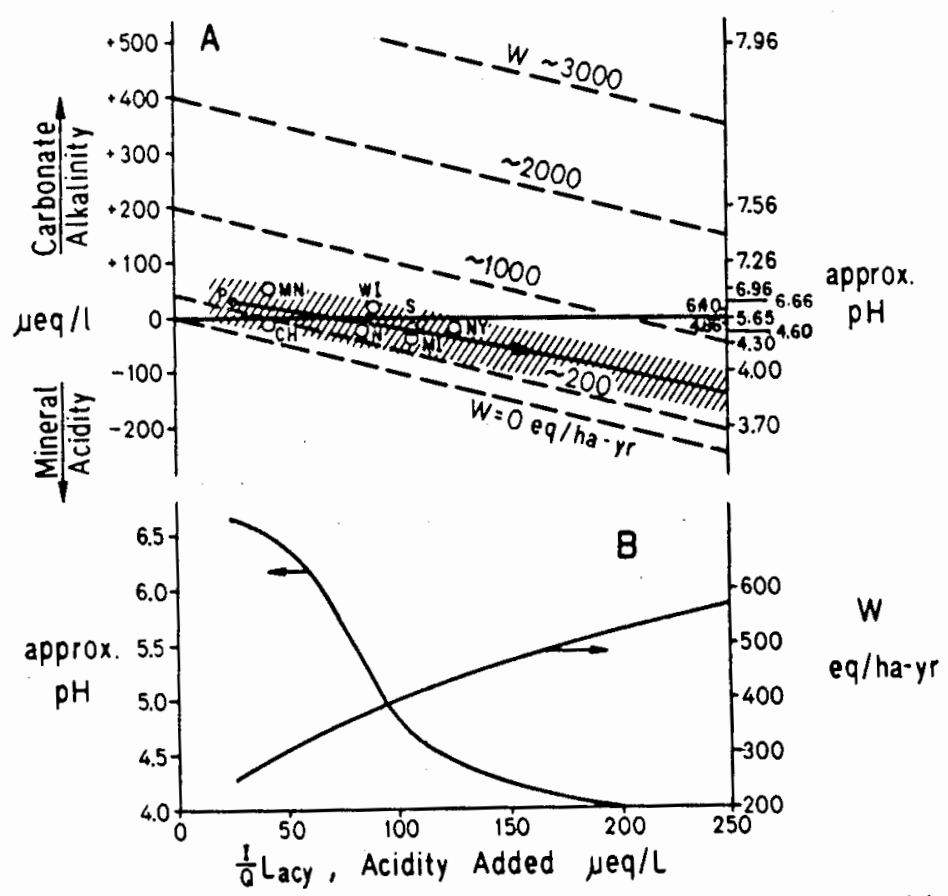

Figure 7. Plot of equation 19 illustrating the effect of precipitation acidity added (I $\left.L_{i l c y} / Q\right)$ on lake alkalinity at steady state. A: Selected sensitive lakes. $\mathrm{MN}=\mathrm{Lake}$ Warpaint, Minnesota; $\mathrm{CH}=$ Lake Cristallina, Switzerland; $\mathrm{WI}=$ Lake Vandercook. Wisconsin; $\mathrm{N}=$ Lake Langtjern, Norway; $\mathrm{S}=$ Lake Gärdsjön, Sweden; $M I=L a k e$ McNearncy, Michigan; $N Y=$ Woods Lake, New York; $p=$ hypothetical lake with $R=100 \mathrm{~cm} / \mathrm{yr}, \mathrm{I} / \mathrm{Q}=2.0$, $\mathrm{k}_{\mathrm{h}}=150 \mathrm{eq} / \mathrm{ha} \cdot \mathrm{yr}, \mathrm{k}_{\mathrm{a}}=100 \mathrm{eq} / \mathrm{ha} \cdot \mathrm{yr}, \mathrm{m}=0.5, \mathrm{~L}_{\mathrm{ref}}=12 \mu \mathrm{eq} \mathrm{l}^{-1}$ (dashed lines are weathering rates and asssume $\mathrm{R}=100 \mathrm{~cm} / \mathrm{yr}$ and $\mathrm{l} / \mathrm{Q}=2.0$ ). B: Titration curve for hypothetical lake and its fractional order weathering (neutralization) rate. 


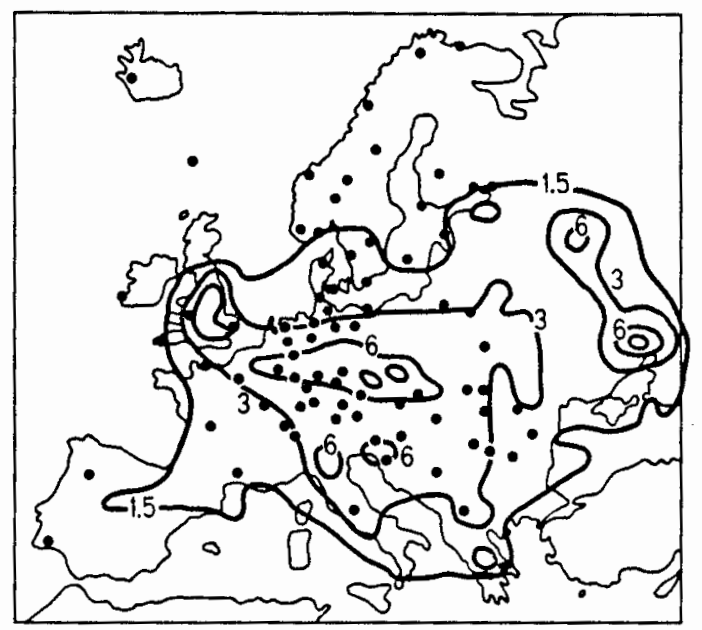

Figure 8. Concentration of total S-deposition in Europe $\left(\mathrm{g} \mathrm{S} / \mathrm{m}^{2} \cdot \mathrm{yr}\right)$ from October 1978 to September 1980 , EMEP Network. Stations for sampling the air and precipitation under the European Monitoring Program.

lakes fall below this hypothetical line and would have an inflection point at about $50 \mu \mathrm{eq}$ $\mathrm{I}^{-1}$, which corresponds to an acidity of precipitation of about $25 \mu \mathrm{eq} \mathrm{\textrm {l } ^ { - 1 }}$ or a $\mathrm{pH}$ of 4.6 . Thus, it is not until the precipitation acidity becomes great enough and exceeds a minimum acid deposition of approx. $200 \mathrm{eq} \mathrm{H}^{+} / \mathrm{ha} \cdot \mathrm{yr}$ that one can expect even the most sensitive lakes to become acidified by acid precipitation. (The acid deposition of 100 $\mathrm{cm} / \mathrm{yr}$ of precipitation at $\mathrm{pH} 4.6$ is $250 \mathrm{eq} \mathrm{H}^{+} / \mathrm{ha} \cdot \mathrm{yr}$.)

Assuming that all of the sulfate is deposited as $\mathrm{H}_{2} \mathrm{SO}_{4}$, the outermost contour line on figure 8 of $1.5 \mathrm{~g} \mathrm{~S} / \mathrm{m}^{2} \cdot \mathrm{yr}$ is equivalent to $310 \mathrm{eq} / \mathrm{ha} \cdot \mathrm{yr}$, or a hydrogen ion concentration of $31 \mu \mathrm{eq} \mathrm{I}^{-1}$ and $100 \mathrm{~cm} / \mathrm{yr}$ of precipitation. This is more than enough acidic deposition to significantly depress the $\mathrm{pH}$ of the most sensitive lakes and streams. Thus, the area vulnerable to lake acidification covers virtually the entire map of figure 8 , but only those lakes with extreme sensitivity, both hydrologic and geologic, have been reported, and the greatest number are situated in Sweden and Norway.

\section{Conclusions}

- Chemical weathering is an important process which helps to neutralize acidic deposition and supply cations $\left(\mathrm{Ca}^{2+}, \mathrm{Mg}^{2+}, \mathrm{Na}^{+}, \mathrm{K}^{+}\right)$and alkalinity to the watershed.

- The genesis of acid precipitation and the final composition of stream water can be inferred from stoichiometric considerations of atmospheric, terrestrial, and aquatic reactions (table 3).

- Watershed which are sensitive to acidic deposition produce only $200-500 \mathrm{eq} / \mathrm{ha} \cdot \mathrm{yr}$ of cations and alkalinity. These watersheds are characterized by extreme geologic and hydrologic sensitivity (fig. 3), and they can be acidified by acidic precipitation less than $\mathrm{pH} 4.3-4.6($ at $100 \mathrm{~cm} / \mathrm{yr}$ precipitation rate) or sulfate deposition greater than $1.0-2.5 \mathrm{~g} \mathrm{~S} / \mathrm{m}^{2} \cdot \mathrm{yr}$ (fig. 7 and 8 ). 
- The kinetics of chemical weathering are fractional order with respect to hydrogen ion and organic ligand concentrations in bulk solution (fig. 4).

- A simple model (equation 19) can be used to illustrate the acidification of lakes in sensitive regions of the world (fig. 8).

\section{ACKNOWLEDGMENTS}

We are indepted to Gerhard Furrer, Rudolf Giovanoli, Laura Sigg, Bernhard Wehrli, Erich Wieland and Jürg Zobrist, to the Swiss National Science Foundation (NFP-14) and to the US Environmental Protection Agency (DDRP-Project) for supporting our research on the chemistry of atmospheric depositions and on their interactions with the environment.

\section{REFERENCES}

1 Stumm, W., Morgan, J.J., and Schnoor, J. L.: Saurer Regen, eine Folge der Störung hydrogeochemischer Kreisläufe. Naturwissenschaften 70, 216-233 (1983).

2 Johnson, D. W., Henderson, S. G., and Todd, D. E.: Evidence of Modern Accumulations of Adsorbed Sulfate in an East Tennessee Forested Uitisol. Soil Sci. 132, 422 (1981).

3 Wright, R. F.: Predicting Acidification of North American Lakes. Norwegian Institute for Water Research, Oslo, Norway, Report 4, 38-51 (1983).

4 Dickson. W.: The Acidification of Swedish Lakes. Inst. Freshw. Res. Drottningholm 54, 8-20 (1975).

5 Gjessing, E.T., Henriksen, A., Johannesen, M., and Wright, R. F., in: Braekke, F.H. (ed.): Impact of Acid Precipitation on Forest and Freshwater Ecosystems in Norway. SNSF-Project: As, Norway, 64 (1976).

6 Wright, R. F., Dale, T., Gjessing, E. T., Hendrey, G., Henriksen, A., Johannesen, M., and Muniz, I. P.: Impact of Acid Precipitation on Freshwater Ecosystems in Norway. Water, Air, Soil Poll. 6, 483-489 (1976).

7 Schofield, C. L.: Acid Precipitation: Effects on Fish, Ambio 5, 228-230 (1976).

8 Likens, G. E., Wright, R. F., Galloway, J. N., and Butier, I. J.: Acid Rain. Sci. Am. 241, 43-51 (1979).

9 Beamish, R. J., and Harvey, H.H.: Acidification of the La Cloche Mountain Lakes, Ontario, and Resulting Fish Mortalities. J. Fish. Res. Bd Can. 29, 1131-1143 (1972).

10 Beamish, R. J.: Acidification of Lakes in Canada by Acid Precipitation and the Resulting Effects on Fishes. Water, Air, Soil Poll. 6, 502-514 (1976).

11 Scheider, W. A., Jefries, D. S., and Dillon, P. J.: Effects of Acidic Precipitation on Precambrian Freshwaters in Southern Ontario. J. Great Lakes Res. 5, 45-51 (1979).

12 Johnson, N. M.: Acid Rain: Neutralization within the Hubbard Brook Eeosystem and Regional Implications. Science 204, 497. 499 (1979).

13 Goldich, S. S.: A Study in Rock Weathering. J. Geol. 46, 17-58 (1938).

14 Press, F., and Siever, R.: Earth, W. H. Freeman and Co., San Francisco 1974.

I5 Van Breeman, N., Driscoll, C. T., and Mulder, J.: Acidic Deposition and Internal Proton Sources in Acidification of Soils and Waters. Nature 307, 599-604 (1984).

16 Menard, H.W. Geology, Resources, and Society. W.H. Freeman and Co., San Francisco 1974.

17 Correns, C. W.: The Experimental Chemical Weathering of Silicates, Clay Miner. Bull. 4, 249-265 (1961).

18 Correns, C.W.: Experiments on the Decomposition of Silicates and Discussion of Chemical Weathering. Clays and Clay Minerals, Proc. Tenth Nat. Conf. Clays and Clay Minerals, p. 443-459 (1963).

19 Stumm, W., Furrer, G., and Kunz, B.: The Role of Surface Coordination in Precipitation and Dissolution of Mineral Phases. Croat. Chem. Acta 56, 593-611 (1983).

20 Schnoor, J. L., and Stumm, W., in: Stumm, W. (ed.): Chemical Processes in Lakes. Wiley Interscience, New York 1985.

21 Stumm, W., Furrer, G., Wieland, E., and Zinder, B., in: Drever, J.I. (ed.): The Chemistry of Weathering. D. Reidel Publishing; Dordrecht and Boston 1985.

22 Schnoor, J. L., Palmer, W. D., Jr., and Glass, G. E., in: Schnoor, J. L. (ed.): Modeling of Total Acid Precipitation Impacts. Butterworth Publishers, Boston 1984. 
23 Fitzpatrick. E. A.: Soils - Their Formation, Classification and Distribution. Longman, New York 1980.

24 Johnson, N.M., Driscoll, C.R., Eaton, J.S., Likens, G.E., and McDowell, W. H.: Acid Rain, Dissolved Aluminum and Chemical Weathering at the Hubbard Brook Experimental Forest. Geochim. Cosmochim. Acta 46, 1421 (1981).

25 Ardakani, M.S. and McLaren, A. D.: Absence of Local Equilibrium in Soil Columns. Soil Sci. Soc. Am. Proc. 4l.877-879 (1977).

26 Reuss, J. O.: Implications of the Ca-Al Exchange System for the Effect of Acid Precipitation on Soils. J. Envir. Qual. 12, 591-595 (1983).

27 Christophersen, N., and Wright, R. F.: Sulfate Budget and a Model for Sulfate Concentrations in Streamwater at Birkenes, Norway. Wat. Resour. Res. 17, 377-389 (1981).

28 Christophersen, N., Seip, H.M., and Wright, R.F.: A Model for Streamwater Chemistry at Birkenes, Norway. Wat. Resour. Res. 18, 977-996 (1982).

29 Cosby, B. J., Hornberger, G. M., Galloway, J. N., and Wright, R. F.: Modeling the Effects of Acid Deposition: Assessment of a Lumped Parameter Model of Soil Water and Streamwater Chemistry. Wat. Resour. Res. 2I, 51-63 (1985).

30 Gaines, G. L., and Thomas, H.C.: Adsorption Studies on Clay Minerals: Il. A Formulation of the Thermodynamics of Exchange Adsorption. J. Chem. Phys. 21, 714-718 (1953).

31 Bloom, P. R., and Grigal, D. F., personal correspondence.

32 Juday, C., and Birge, E. A.: The Transparency, the Color, and the Specific Conductance of the Lake Waters of Northeastern Wisconsin. Trans. Wis. Acad. Sci. Arts. Lett. 28, 205 (1933).

33 Eilers, J.M., Glass, G. E., Webster, K. E., and Rogalla, J. A.: Hydrologic Control of Lake Susceptibility to Acidification. Can. J. Fish Aquat. Sci. 40, 1896-1907 (1983).

34 Schindler, P. W., in: Anderson, M. A., and Rubin. A. (eds.): Adsorption of Inorganics at Oxide Surfaces. Ann Arbor Science Publishers, Ann Arbor, MI, p. $1-49$ (1982).

35 Kummert, R., and Stumm, W.: The Surface Complexation of Organic Acids on Hydrous $\delta-\mathrm{Al}_{2} \mathrm{O}_{3}$. J. Colloid Interface Sci. 75, $373(1980)$.

36 Sigg, L., and Stumm, W.: The Interaction of Anions and Weak Acids with the Hydrous Goethite $(\alpha-\mathrm{FeOOH})$ Surface. Colloids \& Surfaces 2, 101 (1980).

37 Luce, R.W., Bartlet, R.W., and Parks, G. A.: Dissolution Kinetics of Magnesium Silicates. Geochim. Cosmochim. Acta 36, 35-50 (1972).

38 Helgeson, H. C.: Kinetics of Mass Transfer Among Silicates and Aqueous Solutions. Geochim. Cosmochim. Acta $35,421-429$ (1971).

39 Helgeson. H.C.: Kinetics of Mass Transfer Among Silicates and Aqueous Solutions: Correction and Clarification, Geochim. Cosmochim. Acta 36, 1067 1070 (1972).

40 Paces, T.: Steady-State Kinetics and Equilibrium Between Groundwater and Granitic Rock. Geochim. Cosmochim. Acta 37, 2641-2663 (1973).

41 Wollast, R.: Kinetics of the Alteration of K-Feldspar in Buffered Solutions at Low Temperatures. Geochim. Cosmochim. Acta 31, 635-648 (1967).

42 Busenberg, E., and Clemency, C. V.: The Dissolution Kinetics of Feldspars at $25^{\circ} \mathrm{C}$ and $1 \mathrm{Atm} \mathrm{CO}_{2}$ Partial Pressure. Geochim. Cosmochim. Acta 40,41-49 (1976).

43 Berner, R. A., and Holdren, G. R., Jr.: Mechanism of Feldspar Weathering: Some Observational Evidence. Geology 5, 369-372 (1977).

44 Berner, R. A., and Holdren, G. R., Jr.: Mechanism of Feldspar Weathering - II. Observations of Feldspars from Soils. Geochim. Cosmochim. Acta 43, 1173-1186 (1979).

45 Berner, R.A., Sjoberg, E.L., Velbel, M.A., and Krom, M.D.: Dissolution of Pyroxenes and Amphiboles During Weathering. Science 207, 1205-1206 (1980).

46 Holdren, G. R., Jr., and Berner, R.A.: Mechanism of Feldspar Weathering - 1. Experimental Studies. Geochim. Cosmochim. Acta 43,1161-1171 (1979).

47 Schott, J., Berner, R. A., Sjöberg, E. L.: Mechanism of Pyroxene and Amphibole Weathering - I. Experimental Studies of Iron-Free Minerals. Geochim. Cosmochim. Acta 45, 2123-2135 (1981).

48 Busenberg, E., and Plummer, L. N.: The Kinetics of Dissolution of Dolomite in $\mathrm{CO}_{2}-\mathrm{H}_{2} \mathrm{O}$ Systems at 1.5 to $65^{\circ} \mathrm{C}$ and 0 to 1 ATM $\mathrm{PCO}_{2}$. Am. J. Sci. 282, 45-78 (1982).

49 Grandstaff, D.E.: Some Kinetics of Bronzite Orthopyroxene Dissolution. Geochim. Cosmochim. Acta 41, 1097-1103 (1977).

50 Furuichi, R., Sato, N., and Okamoto, G.: Reactivity of Hydrous Ferric Oxide Containing Metallic Cations. Chimia 23, 455 (1969). 
51 Bloom, P. R.: The Kinetics of Gibbsite Dissolution in Nitric Acid. Soil Sci. Soc. Am. J, 47, $164-168$ (1983).

52 Fung, P.C., and Sanipelli, G. G.: Surtace Studies of Feldspar Dissolution Using Replication Combined with Electron Microscope and Spectroscopic Techniques. Geochim. Cosmochim. Acta 46, 503-511 (1982).

53 Garrels, R. M., and Christ, C. L.: Solutions, Minerais. and Equilibria. Harper and Row, New York 1965.

54 Garrels, R. M., and MacKenzie, F.T., in: Gould, R.F. (ed.): Equilibrium Concepts in Natural Water Systems. Advances in Chemistry, Series 67. Amcrican Chemical Society, New York 1967.

55 Garrels, R.M., in: Abelson, P.H. (ed.): Research in Geochemistry, vol. 2. John Wiley \& Sons, New York 1967.

56 Bricker, O.P., Godfrey, A. E., and Clcaves, E.T., in: Gould. G. B. (ed.): Trace Inorganics in Water. Advances in Chemistry, Series 73, American Chemical Society, New York 1968.

57 Katz, B.G., Bricker, O.P., and Kennedy, M. M.: Geochemical Mass Balance Relationships for Selected Ions in Precipitation and Stream Water, Catoctin Mountains, Maryland. US Geological Survey Paper, in preparation.

58 Drever, J. I.: Geochemistry of Natural Waters. John. Wiley Interscience, New York 1983.

59 Miller, W. R., and Drever, J. I.: Chemical Weathering and Related Controls on Surface Water Chemistry in the Absaroka Mountains, Wyoming. Geochim. Cosmochim. Acta 41, 1693-1702 (1977).

60 Krug. E. C., and Frink, C. R.: Acid Rain on Acid Soil: A New Perspective. Science 221, 520-526 (1983).

6! Abclson. P. H.: Effects of $\mathrm{SO}_{2}$ and $\mathrm{NO}_{x}$ Emissions. Science 226. 1263 (1984).

62 Oppenheimer, M., Galloway, J.N., Likens, G. E., and Norton. S. A.: Acid Deposition. Science 227. 1155$1156(1985)$

63 Cowling, E. B.: Acid Precipitation in Historical Perspective. Envir. Sci. Technol. 16. 110A-123A (1982)

64 Richter, D. D.: Comment on 'Acid Precipitation in Historical Perspecrive' and 'Effects of Acid Precipitation', Envir. Sci. Technol. 17, 568-570 (1983).

65 Henriksen, A.: A Simple Approach for Identifying and Measuring Acidification in Freshwater. Nature 278 , $542-545$ (1979).

66 Henriksen, A.: Comment on 'Acid Precipitation in Historical Perspective' and 'Effects of Acid Precipitation'. Envir. Sci. Technol. 18, 631-632 (1984).

67 Richter, D. D.: Closing Comment. Envir. Sci. Technol. 18.632-634 (1984).

68 Rosenquist, I. Th.: Acid Precipitation and Other Possible Sources tor Acidification of Rivers and Lakes. Sci. Tot. Env. 10, 39-49 (1978).

69 Cronan, C.S., and Schofield, C. L.: Aluminum Leaching Response to Acid Precipitation: Effects on High Elevation Watersheds in the Northeast. Science 204, 30+305 (1979).

70 Ulrich, B., Mayer, R., and Khanna, P.K.: Chemical Changes due to Acid Precipitation in a Loess-Derived Soil in Central Europe. Soil Sci. 130, 193-199 (1980).

71 Driscoll, C.T., and Likens, G.E.: Hydrogen lon Budget of an Aggrading Forcsted Ecosystem. Tellus 34, 283-292 (1982)

72 La Zerte, B. D., and Dillon, P. J.: Relative Importance of Anthropogenic versus Natural Sources of Acidity in Lakes and Streams of Central Ontario. Can. J. Fish. Aquat. Sci. 4l, 1664-1677 (1984).

73 Goldstein, R. A., and Gherini, S. A.: The Integrated Lake-Watershed Acidification Study, vol. 4: Summary of Major Results. Tetra-Tech, Inc., Lafayette, Calif. (1984).

74 Richter, D. D., Johnson, D.W., and Todd, D. E.: Atmospheric Sulfur Deposition, Neutralization, and Ion Leaching in Two Deciduous Forest Ecosystems. J. Envir. Qual. 12, 263-270 (1983).

75 van Breemen, N., Burrough, P.A., Velthorst, E.J., san Dobben. H.F., de Wit, T., Ridder, T.B., and Reijinders, H.F.R.: Soil Acidification from Atmospheric Ammonium Sulphate in Forest Canopy Throughfall. Nature 299, 548-550 (1982)

76 Paces, T.: Rate Constants of Dissolution Derived from the Measurements of Mass Balances in Hydrological Catchments. Geochim. Cosmochim. Acta 47, 1855-1863 (1983).

77 Vebel, M. A.: Mineral Transformations During Rock Weathering. and Geochemical Mass-balances in Forested Watersheds of the Southern Appalachians. Ph. D. dissertation. Yale Univ., 175 p. (1984).

78 Siegel, D. I., and Pfannkuch, H. O.: Silicate Dissolution Infuence on Filson Creek Chemistry, Northeastern Minnesota. Bull. Geol. Soc. Am. 95, 1446-1453 (1984).

79 Wehrli, B., and Wicland, E.: The Chessboard - A Model for Two-Dimentional Distributions of Interface Species. EAWAG News 20/21, 9-12 (1986).

80 Busenberg, E., and Clemency, C. V.: The Dissolution Kinetics of Feldspars at $25^{\circ} \mathrm{C}$ and 1 atm $\mathrm{CO}_{2} \mathrm{Partial}$ Pressure. Geochim. Cosmochim. Acta 40, 41-49 (1976) 
81 Grandstafi. D.E.. in: Rates of Chemical Weathering of Rocks and Minerals. Academic Press, New York 1986.

82 Cronce. R.C.. Kardos, L.T., and Ciolkosz, E. J.: The Effect of Soil on the Renovation of Acid Coal Mine Drainage Water. J. Envir. Qual. 9, 621-626 (1980).

83 Ciolkosz. E. J.. Kardos. L. T., and Beers, W. F.: The Effect of Acid Mine Drainage Water on Two Pennsylvania Soils. Soil Sci. 127, 102-107 (1979).

84 Cook. R. B.. Kelly, C. A., Schindler, D.W., and Turner, M. A.: Mechanisms of Hydrogen Ion Neutralization in an Experimentally Acidified Lake. Limnol. Oceanogr. 31, 134-148 (1986).

85 Schnoor. J. L.. Nikolaidis, N.P., and Glass, G. E.: Lake Resources at Risk to Acidic Deposition in the Upper Midwest. J. Wat. Pollut. Control Fed. 58, 139-148 (1986).

86 Dillon. P. J.. Jelfries. D. S., Scheider, W. A., and Yan, N. D.: SNSF Proc. Intl. Conf. Eco. Impact Acid Precip. 212-213 (1980).

Addresses of the authors: Jerald L. Schnoor, Dept. of Civil and Environmental Engineering, University of lowa, Iowa City lowa 52242. USA - Werner Stumm, EAWAG, CH-8600 Dübendorf. 